\title{
Health Consequences for E-Waste Workers and Bystanders-A Comparative Cross-Sectional Study
}

\author{
Damian Fischer ${ }^{1}$, Fatima Seidu ${ }^{2}$, Jennie Yang ${ }^{1} \mathbb{C}$, Michael K. Felten ${ }^{1}$, Cyryl Garus ${ }^{1}$, \\ Thomas Kraus ${ }^{1}$, Julius N. Fobil ${ }^{3}$ and Andrea Kaifie ${ }^{1, *(D)}$ \\ 1 Institute for Occupational, Social, and Environmental Medicine, Medical Faculty, RWTH Aachen University, \\ Pauwelsstrasse 30, 52074 Aachen, Germany; damian.fischer@rwth-aachen.de (D.F.); \\ jennie.yang@rwth-aachen.de (J.Y.); mfelten@ukaachen.de (M.K.F.); cgarus@ukaachen.de (C.G.); \\ tkraus@ukaachen.de (T.K.) \\ 2 GIZ Ghana Country Office, 7 Volta Street, Accra, Ghana; seidufa@yahoo.de \\ 3 Department of Biological, Environmental and Occupational Health Sciences, School of Public Health, \\ University of Ghana, P.O. Box LG13, Legon, Ghana; jfobil@ug.edu.gh \\ * Correspondence: akaifie@ukaachen.de; Tel.: +49-241-803-5345
}

Received: 23 January 2020; Accepted: 25 February 2020; Published: 27 February 2020

\begin{abstract}
Informal e-waste recycling is associated with several health hazards. Thus far, the main focus of research in the e-waste sector has been to assess the exposure site, such as the burden of heavy metals or organic pollutants. The aim of this study was to comprehensively assess the health consequences associated with informal e-waste recycling. A questionnaire-based assessment regarding occupational information, medical history, and current symptoms and complaints was carried out with a group of $n=84$ e-waste workers and compared to a control cohort of $n=94$ bystanders at the e-waste recycling site Agbogbloshie. E-waste workers suffered significantly more from work-related injuries, back pain, and red itchy eyes in comparison to the control group. In addition, regular drug use was more common in e-waste workers ( $25 \%$ vs. $6.4 \%$ ). Both groups showed a noticeable high use of pain killers (all workers 79\%). The higher frequency of symptoms in the e-waste group can be explained by the specific recycling tasks, such as burning or dismantling. However, the report also indicates that adverse health effects apply frequently to the control group. Occupational safety trainings and the provision of personal protection equipment are needed for all workers.
\end{abstract}

Keywords: occupational exposure; occupational health and safety; Agbogbloshie; ergonomic burden; back pain; drug abuse

\section{Introduction}

Year after year, finding a solution to the global problem of electric and electronic waste (e-waste) is becoming increasingly urgent [1]. In West Africa, Ghana and Nigeria, as the main import centers, have established themselves as the most important trade routes for used electrical and electronic equipment (UEEE) on the continent [2]. UEEE at the end of its life span, especially that imported from Europe, leads to the creation of hundreds of thousands of tons of electronic waste every year in Ghana alone $(179,000 \mathrm{t}$ in 2009) [2].

The accumulation of this amount of electronic waste drives the growth of the second largest e-waste processing site in West Africa, which has achieved international attention as one of the world's Top 10 toxic threats 2013 (according to Pure Earth/Blacksmith Institute) [3]. Under minimal and inefficient governmental control, an informal sector of e-waste recycling emerged west of the capital of Ghana, Accra, more than two decades ago [4]. The $16 \mathrm{~km}^{2}$ Agbogbloshie district in the Korle Lagoon, known locally as Sodom and Gomorrah, was leased in 1994 by the informal Greater Accra Scrap Dealers' Association of Ghana (GASDA) from the National Youth Authority (NYA) [4,5]. 
Job opportunities on the scrap yard attract migrants from the disadvantaged rural areas in the north of the country, particularly for members of ethnic minority groups whose chances of finding a job in the formal sector are virtually nonexistent [2]. In 2016, 3000 workers were employed at the scrap yard, of whom 1500 were registered with GASDA [4]. The primitive methods used to recover valuable metals from the hazardous electronic waste expose workers to high levels of occupational risks. The most basic tools are used to dismantle the devices. Cables are burned using insulating foam from dismantled refrigerators or car tires as fuel to melt off their insulation. Most of the workers are not wearing any personal protection against the highly contaminated smoke and suffer from cuts and burns [6].

The burden on the workers was clearly shown in previous research: soil samples from Agbogbloshie showed significantly elevated levels of trace metals and PBDE (polybrominated diphenyl ethers) [7-9]. In personal air samples, increased concentrations of aluminum, copper, iron, lead, and zinc values could be detected [7]. Cadmium and lead were significantly elevated in blood samples of e-waste workers [10,11]. Urine samples also showed elevated levels of PAH (polycyclic aromatic hydrocarbons) [12], cadmium, chromium, nickel [11], iron, antimony, lead, and various arsenic species [10,13].

However, the most acute medical needs of the scrapyard workers remain unassessed. Most published studies focus on the external exposure to hazardous substances, but not the health consequences caused by this exposure. Health effects associated with e-waste processing, in particular in vulnerable groups, such as children and pregnant women, have been partially described previously but still remain neglected [14]. In interviews with e-waste workers carried out by Asampong et al. (2015), serious urgent health problems at the scrapyard were addressed for the first time [15].

Therefore, it seems obvious that a comprehensive analysis, not only of the exposure side (stresses) but also of the health consequences caused by the exposure (strains), is essential for an efficient occupational medical intervention for e-waste workers in order to minimize occupational hazards and improve their health and safety. Regarding the assessment of health effects associated with e-waste processing in Agbogbloshie, only two studies addressed the occupation related stress-strain axis. Burns et al. interviewed workers and found an association between noise exposure and the elevation in average heart rate as well as the number of injuries [16,17]. In Nigeria, the other important West African UEEE hub, only one study investigated a high rate of injuries among workers in the e-waste sector [18].

The focus of this study was to comprehensively assess the health effects of e-waste processing at the Agbogbloshie recycling site. To differentiate the additional health burden that is associated with e-waste recycling, we compared our findings in e-waste workers with those working in the vicinity of the scrapyard and frequent visitors not actively involved in recycling work (bystanders).

\section{Materials and Methods}

\subsection{Study Population}

The study was carried out in May 2019 at Agbogbloshie, Accra, Ghana. Subjects were recruited at a medical care unit at the recycling site as part of a free two-day health checkup by the Ghana Health Service and directly at their place of work during visits over three weeks. This study was approved by the Ethics Committee of Rheinisch-Westfälische Technische Hochschule Aachen University (EK 083-19) and all subjects gave their informed consent for participation. The study population consisted of e-waste workers $(n=84)$ and non-e-waste worker (bystander, $n=94)$. The e-waste workers were allocated to occupational subgroups according to the predominant job tasks of dismantlers $(n=52)$, burners $(n=21)$, and collectors $(n=11)$. The dismantlers dismantle the electrical and electronic devices, the burners burn cables and other components, and the collectors search the ashes for valuable metals. The control group consisted of people working in and around the Agbogbloshie recycling site without being directly involved into e-waste processing. Among the non-e-waste workers (bystander), onion carriers $(n=28)$ from the adjacent onion market, scraps traders $(n=15)$, sellers of food and other articles $(n=33)$, metal workers $(n=6)$, repairers $(n=3)$, and others (e.g., tailors, security guards, 
and drivers; $n=9$ ) were identified. Onion carriers, for example, loaded onion sacks from and onto trucks by the main road, scraps traders provided workers with devices, and sellers crossed the scrap yard daily with their goods coming from shops at the periphery of the yard.

\subsection{Questionnaire}

All subjects completed a questionnaire in the presence of the study team, which was supported by an interpreter if required. The questionnaire was completed at the medical care unit during the health checkup or directly at the workplace, in dependence of the recruitment situation. The questionnaire included items on demographic characteristics, the occupational situation, and medical history. The questionnaire was divided into the following five sections:

1. Personal information: Age, sex, marital status, level of education, religion, and residency.

2. Occupational information: Working with e-waste, specific task, duration of working, use of personal protection equipment, and specification of control group occupation.

3. Habits/Lifestyle: Dietary habits, smoking, and drug use.

4. Medical information: Current complaints, such as diseases of the skin, infections, psychiatric disorders, diseases of the eyes and ears, cardiovascular diseases, lung diseases, musculoskeletal diseases, and injuries.

5. Pre-existing medical care: Location of medical care, frequency, and health insurance status.

Work exposure was queried with items on skin contact with chemicals or metals; volume exposure; inhalation of smoke, dust, or gases; great physical stress at work; and traffic accidents during work. Concerning skin symptoms and shortness of breath, the subjects were specifically asked whether they suspected an association with their work. Given the lack of clinical diagnosis, the questions were prepared in accordance with ICD-10 (International Statistical Classification of Diseases and Related Health Problems) specifications and after thorough consultation with occupational physicians and local project support.

\subsection{Statistical Analyses}

Clinical data were collected and analyzed using SAS Software (SAS 7.1, SAS Institute Inc., Cary, NC, USA). First, descriptive analyses of general characteristics, medical conditions, and medical care and insurance status were performed for characterization of the cohort. Possible associations between current symptoms, diseases, and specific work tasks were investigated. We used chi-square tests to describe the distribution of categorical variables between the different subtypes. All statistical tests were two-sided, and $p<0.05$ was used as the level of significance.

\section{Results}

The study population ( $n=178$ ) consisted of $n=84$ e-waste workers (EW) and $n=94$ bystanders (BY). Figure 1 shows the distribution of the EW and BY into their respective occupational subgroups. 


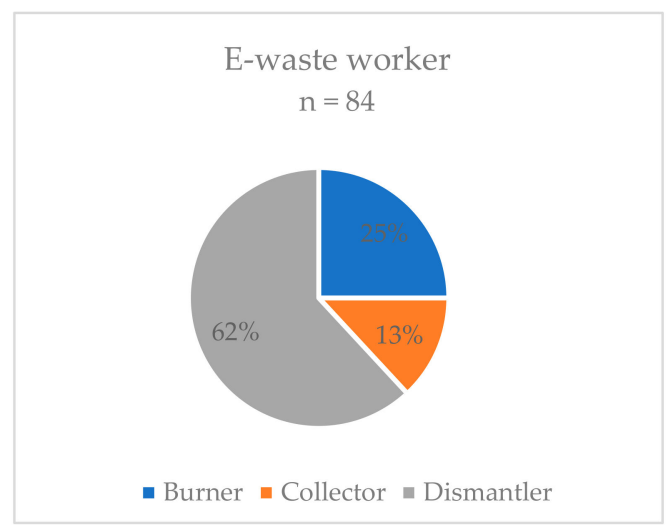

(a)

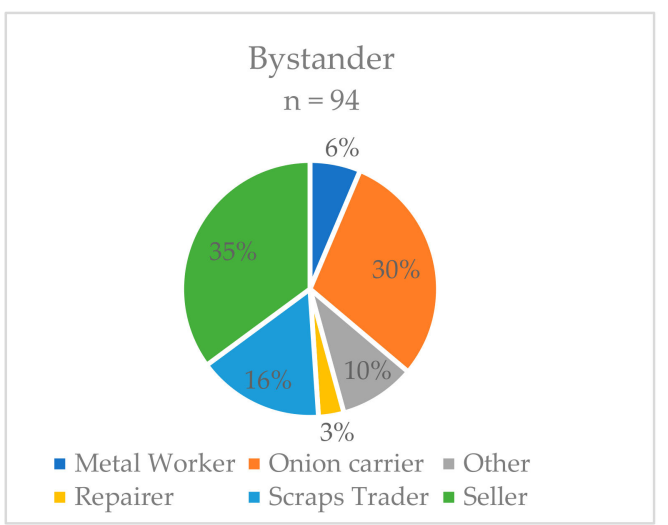

(b)

Figure 1. Job tasks of e-waste workers (a) and bystanders (b) (in percent of subgroups, total $n=178$ ).

There were no age differences between the groups (EW mean age $=27$ years, range $=18-59$ years; BY mean age $=28$ years, range $=18-50$ years $)($ Table 1$)$. Among the EW, $97.6 \%$ were male, while, among the BY, $71.3 \%$ were male. School education differed between the groups with more subjects without school education for BY (EW 26.2\% and BY 43.0\%) (Table 1). The origin of the EW and BY differed significantly, as shown in Table 1 (100\% of EW were from Ghana and 59.6\% or BY were from Ghana).

Table 1. Selected demographic characteristics of E-waste workers and bystanders at Agbogbloshie scrap yard.

\begin{tabular}{|c|c|c|c|c|c|}
\hline \multicolumn{2}{|c|}{ Demographic Characteristics } & \multirow{2}{*}{$\begin{array}{c}\text { All }(n=178) \\
28\end{array}$} & \multirow{2}{*}{$\begin{array}{c}\text { E-Waste } \\
\text { Workers }(n=84) \\
27\end{array}$} & \multirow{2}{*}{$\begin{array}{c}\begin{array}{c}\text { Bystanders } \\
(n=94)\end{array} \\
28\end{array}$} & \multirow{2}{*}{$\begin{array}{c}\begin{array}{c}p \text {-Value } \\
\text { (Chi-Square) }\end{array} \\
\text { ns }\end{array}$} \\
\hline Age (years) & mean & & & & \\
\hline Sex & male & $149(83.7)$ & $82(97.6)$ & $67(71.3)$ & $<0.05$ \\
\hline \multirow{3}{*}{ Marital status $n(\%)$} & Divorced & $5(2.8)$ & $3(3.6)$ & $2(2.1)$ & ns \\
\hline & Married & $93(52.3)$ & $44(52.4)$ & $49(52.1)$ & \\
\hline & Single & $80(44.9)$ & $37(44.1)$ & $43(45.7)$ & \\
\hline \multirow{6}{*}{ Education $n(\%)$} & & $n=177$ & $n=84$ & $n=93$ & $<0.05$ \\
\hline & None & $62(35.0)$ & $22(26.2)$ & $40(43.0)$ & \\
\hline & Primary & $38(21.5)$ & $20(23.8)$ & $18(19.4)$ & \\
\hline & Junior High & $47(26.6)$ & $30(35.7)$ & $17(18.3)$ & \\
\hline & Senior High & $26(14.7)$ & $11(13.1)$ & $15(16.1)$ & \\
\hline & Tertiary & $4(2.3)$ & $1(1.2)$ & $3(3.2)$ & \\
\hline \multirow{2}{*}{ Origin $n(\%)$} & Ghana & $140(78.7)$ & $84(100.0)$ & $56(59.6)$ & $<0.05$ \\
\hline & Other countries & $38(21.4)$ & $0(0.0)$ & $38(40.4)$ & \\
\hline
\end{tabular}
ns $=$ not significant.

As shown in Table 2, significant differences between the two groups were found in substance abuse, such as the inhalation of cannabis (EW 25.0\% and BY 6.4\%). The use of a regular medication, mainly in the form of painkillers, was elevated among both groups (57.5\%). Regarding access to medical care, the subjects were asked about registration in the national health insurance, as well as the use of different institutions to access medical care (Table 2). Most subjects got access to medical care by visiting pharmacies (EW 82.5\% and BY 72.5\%). Only 44.4\% sought out hospitals to obtain medical care. Only $35 \%$ of the subjects were able to show valid registration in the national health insurance scheme (46.3\% EW and 27.5\% BY). EW were asked about the use of PPE (Table 2). Overall, 25.3\% reported that they wore some kind of protective equipment, of whom $57.1 \%$ used safety boots and $9.5 \%$ each wore safety glasses, dust masks, and helmets. 
Table 2. Selected health characteristics of the e-waste workers and bystanders on the Agbogbloshie scrap yard.

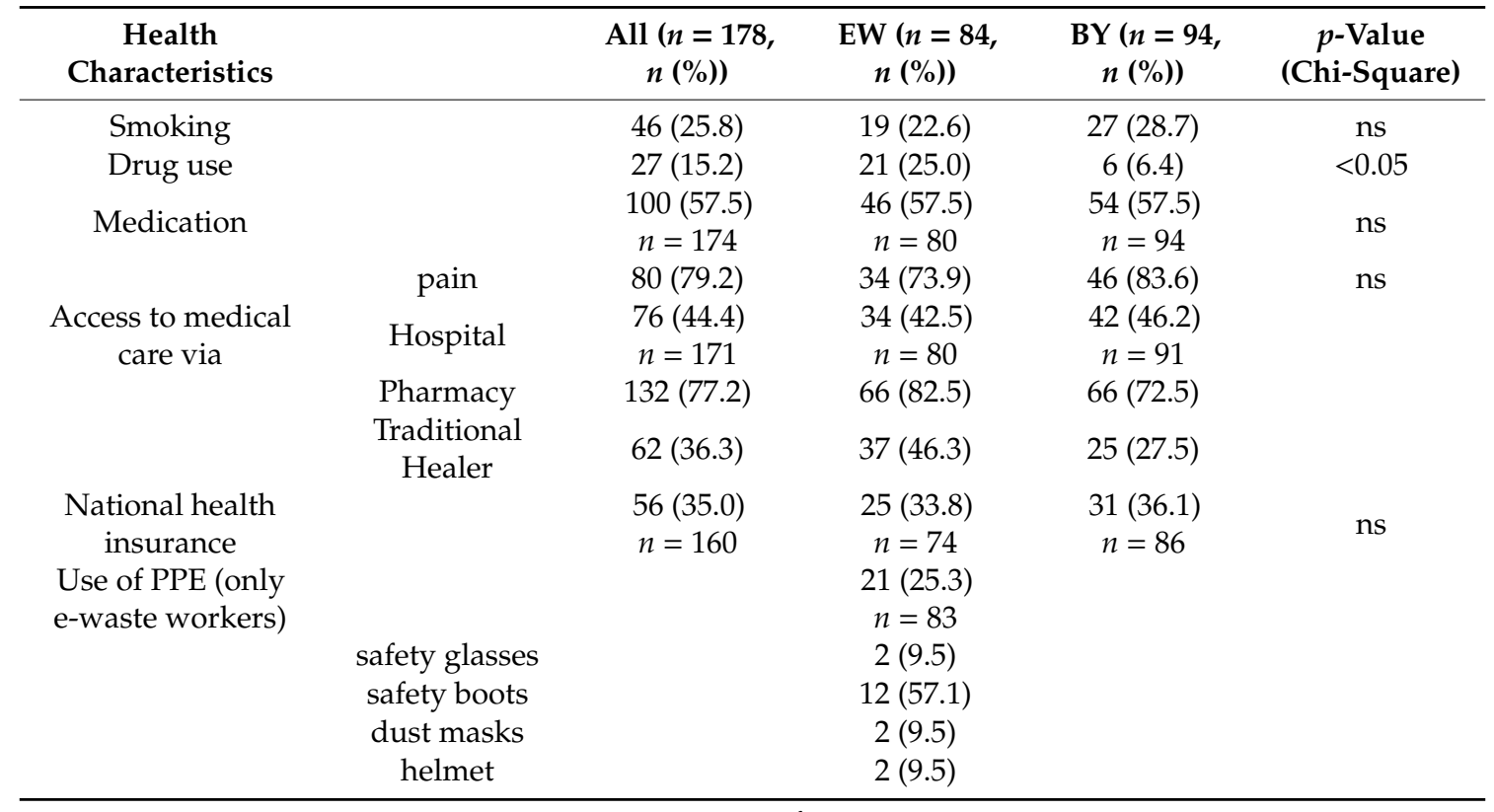

ns = not significant.

Regarding symptoms and diseases, there were no significant differences between the groups regarding infectious diseases, malaria, diabetes, gastrointestinal symptoms, high blood pressure or other cardiovascular symptoms, respiratory diseases, or psychiatric diseases (Table 3). High prevalences could be observed in both groups in reports of malaria in the last year $(77.0 \%)$, digestive problems $(62.9 \%)$, cough $(64.2 \%)$, and various symptoms of mental problems (anxiety $45.2 \%$, depression $34.5 \%$, and posttraumatic stress disorder $46.9 \%$ ). Significant differences between EW and BY for red itchy eyes (EW 67.9\% and BY 51.6\%), back pain (EW 91.6\% and BY 79.6\%), and work-related injuries (EW 75.0\% and BY $42.6 \%$ ) were observed (Table 3). No significant differences could be detected for skin diseases, shortness of breath, eye injuries, or hearing loss (Table 3). Half of the workers suspected an association between the symptom shortness of breathing and their occupation. For skin diseases, $41.7 \%$ of the e-waste workers but only $20.7 \%$ of the BY suggested an association between symptom and occupation (Table 3).

Table 3. Selected symptoms and diseases of the e-waste workers and bystanders on the Agbogbloshie scrap yard.

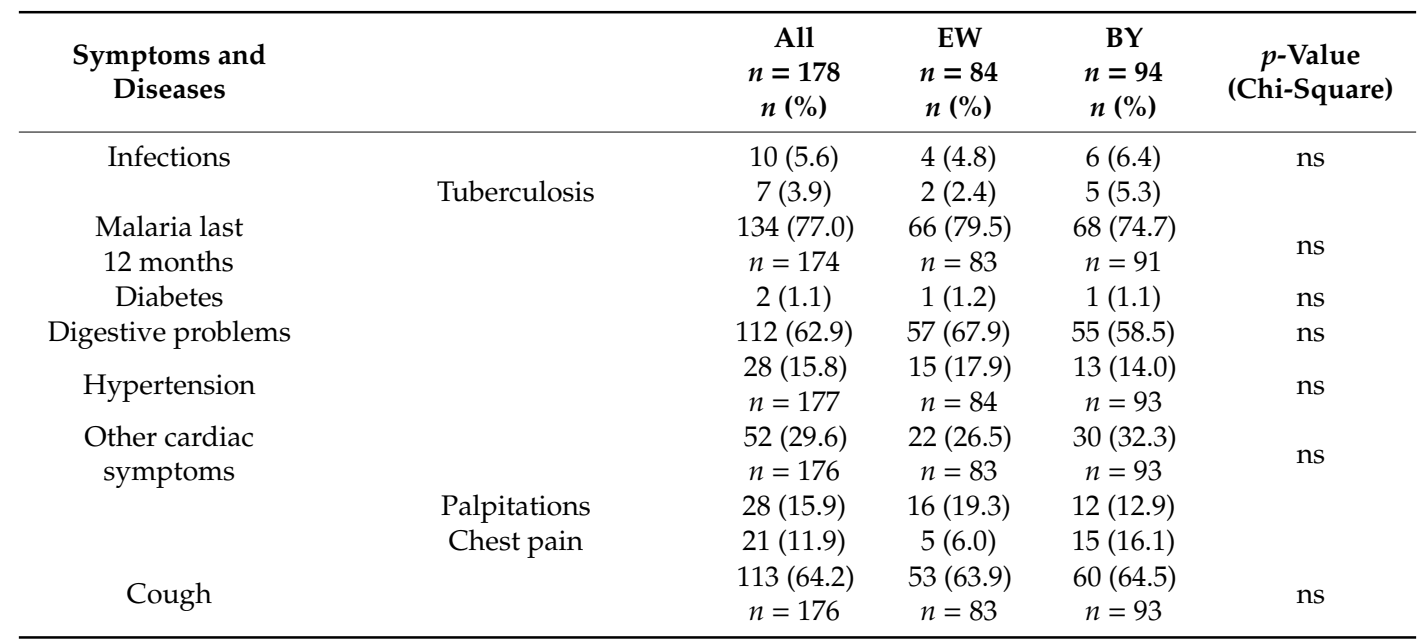


Table 3. Cont.

\begin{tabular}{|c|c|c|c|c|c|}
\hline $\begin{array}{l}\text { Symptoms and } \\
\text { Diseases }\end{array}$ & & $\begin{array}{c}\text { All } \\
n=178 \\
n(\%)\end{array}$ & $\begin{array}{c}\text { EW } \\
n=84 \\
n(\%)\end{array}$ & $\begin{array}{c}\text { BY } \\
n=94 \\
n(\%)\end{array}$ & $\begin{array}{c}p \text {-Value } \\
\text { (Chi-Square) }\end{array}$ \\
\hline \multirow[t]{3}{*}{ Mental disorders } & Symptoms of anxiety & $\begin{array}{l}68(38.4) \\
n=177\end{array}$ & $\begin{array}{c}38(45.2) \\
n=84\end{array}$ & $\begin{array}{c}30(32.3) \\
n=93\end{array}$ & ns \\
\hline & Symptoms of depression & $61(34.5)$ & $30(35.7)$ & $31(33.3)$ & ns \\
\hline & $\begin{array}{l}\text { Symptoms of posttraumatic } \\
\text { stress disorder }\end{array}$ & $83(46.9)$ & $44(52.4)$ & $39(41.9)$ & ns \\
\hline \multirow[t]{5}{*}{ Skin symptoms } & & $\begin{array}{l}65(36.7) \\
n=177\end{array}$ & $\begin{array}{c}36(43.4) \\
n=83\end{array}$ & $\begin{array}{c}29(30.9) \\
n=94\end{array}$ & ns \\
\hline & itching & $55(31.1)$ & $33(39.8)$ & $22(23.4)$ & \\
\hline & light sensitivity & $6(3.4)$ & $1(1.2)$ & $5(5.3)$ & \\
\hline & pain & $13(7.4)$ & $3(3.6)$ & $10(10.6)$ & \\
\hline & caused by work ${ }^{1}$ & $21(32.3)$ & $15(41.7)$ & $6(20.7)$ & \\
\hline \multirow[t]{2}{*}{ Shortness of breath } & & $\begin{array}{l}49(27.8) \\
n=176\end{array}$ & $\begin{array}{c}25(30.1) \\
n=83\end{array}$ & $\begin{array}{c}24(25.8) \\
n=93\end{array}$ & ns \\
\hline & caused by work $^{1}$ & $24(49.0)$ & $12(48.0)$ & $12(50.0)$ & \\
\hline Red itchy eyes & & $\begin{array}{c}105(59.3) \\
n=177\end{array}$ & $\begin{array}{c}57(67.9) \\
n=84\end{array}$ & $\begin{array}{c}48(51.6) \\
n=93\end{array}$ & $<0.05$ \\
\hline Eye injuries & & $\begin{array}{l}42(23.7) \\
n=177\end{array}$ & $\begin{array}{c}24(28.6) \\
n=84\end{array}$ & $\begin{array}{c}18(19.4) \\
n=93\end{array}$ & ns \\
\hline Hearing loss & & $\begin{array}{l}28(15.8) \\
n=177\end{array}$ & $\begin{array}{c}14(16.7) \\
n=84\end{array}$ & $\begin{array}{c}14(15.1) \\
n=93\end{array}$ & ns \\
\hline \multirow[t]{3}{*}{ Back pain } & & $\begin{array}{c}150(85.2) \\
n=176\end{array}$ & $\begin{array}{c}76(91.6) \\
n=83\end{array}$ & $\begin{array}{c}74(79.6) \\
n=93\end{array}$ & $<0.05$ \\
\hline & neck & $77(43.8)$ & $37(44.6)$ & $40(43.0)$ & \\
\hline & back & $138(78.4)$ & $73(88.0)$ & $65(69.9)$ & \\
\hline \multirow[t]{3}{*}{ Work-related injuries } & & $103(57.9)$ & $63(75.0)$ & $40(42.6)$ & $<0.05$ \\
\hline & cuts & $95(53.4)$ & $60(71.4)$ & $35(37.2)$ & \\
\hline & burns & 35 (19.7) & $23(27.4)$ & $12(12.8)$ & \\
\hline
\end{tabular}

${ }^{1}$ Workers were asked if they suspect an association between the symptom and their occupation. $\mathrm{ns}=$ not significant.

When relating certain symptoms and diseases with specific job tasks, we only observed a significant correlation between skin disease and dermal contact to chemicals or metals for all workers $(p<0.05)$. No significant associations could be observed for any of the following combinations: hard physical work and back pain or numbness of extremities, exposure to noise and hearing loss, and inhalation of smoke and shortness of breath (Table 4).

Table 4. Association between specific occupational exposures and medical conditions (for all workers, $n=178)$.

\begin{tabular}{|c|c|c|c|c|}
\hline & \multicolumn{2}{|c|}{ Occupational Exposure } & \multirow{2}{*}{ Sum $n(\%)$} & \multirow{2}{*}{$p$-Value (Chi-Square) } \\
\hline & Yes $n(\%)$ & No $n(\%)$ & & \\
\hline \multicolumn{5}{|c|}{ Dermal contact to chemicals or metals } \\
\hline Skin symptoms & $44(43.1)$ & $20(27.0)$ & $64(36.0)$ & $<0.05$ \\
\hline \multicolumn{5}{|c|}{ Hard physical work } \\
\hline Back pain & $136(85.0)$ & $14(87.5)$ & $150(84.3)$ & ns \\
\hline Numbness & $67(49.2)$ & $5(35.7)$ & $72(40.4)$ & ns \\
\hline \multicolumn{5}{|c|}{ Volume exposure } \\
\hline Hearing loss & $22(15.6)$ & $6(16.7)$ & $28(15.7)$ & ns \\
\hline \multicolumn{5}{|c|}{ Inhalation of smoke } \\
\hline Shortness of breath & $45(28.5)$ & $4(23.5)$ & 49 (27.5) & ns \\
\hline & \multicolumn{2}{|c|}{ Drug Use } & & \\
\hline & Yes $(\%)$ & No $(\%)$ & & \\
\hline Work-related injuries & $21(77.8)$ & $82(54.3)$ & $103(57.9)$ & $<0.05$ \\
\hline
\end{tabular}


The distribution of injury location is shown in Figure 2, with hand injuries accounting for most injuries, followed by arms and legs. A significant correlation between work-related injuries and drug use among all subjects could be determined (Table 4).

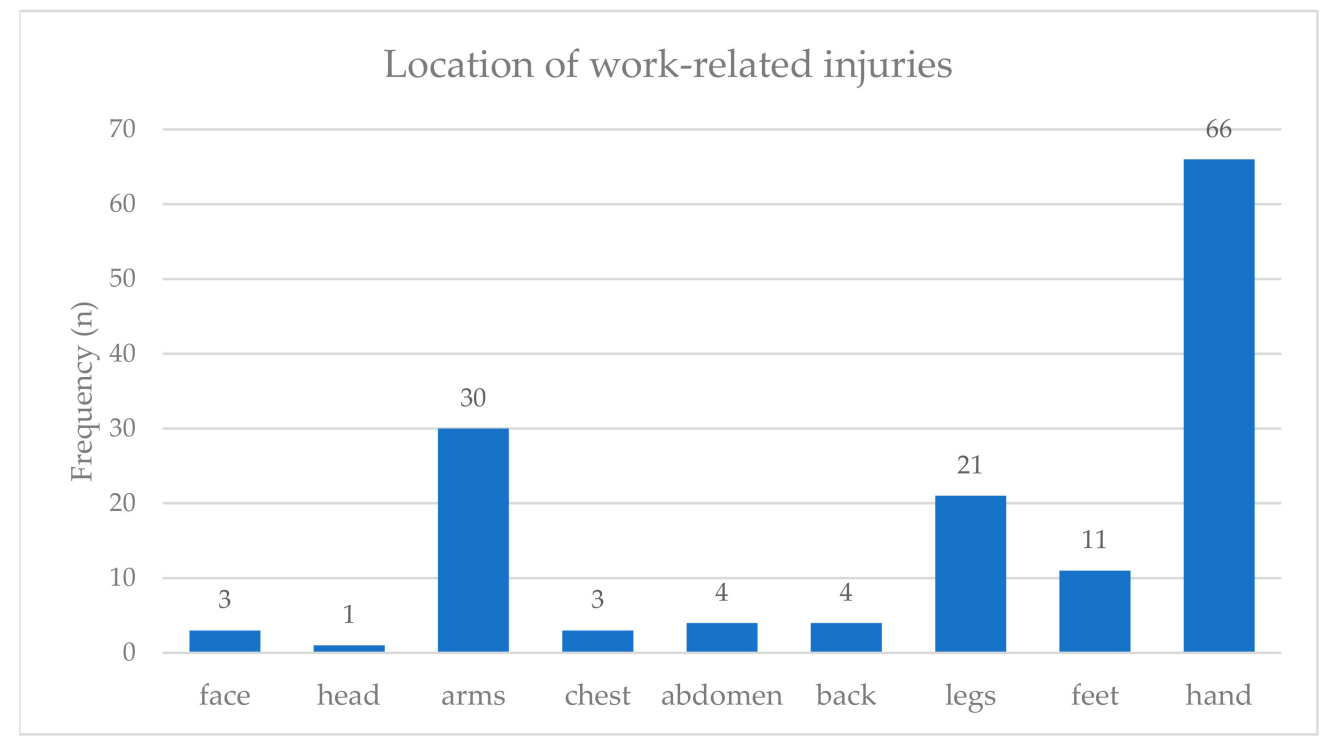

Figure 2. Distribution of the location of work-related injuries for all e-waste workers and bystanders at the scrap yard $(n=178)$.

Back pain was distributed differently among the different occupational groups, as depicted in Figure 3. Here, the prevalence was particularly high for the EW, with $100 \%$ of collectors and $92 \%$ of dismantlers complaining about back pain.

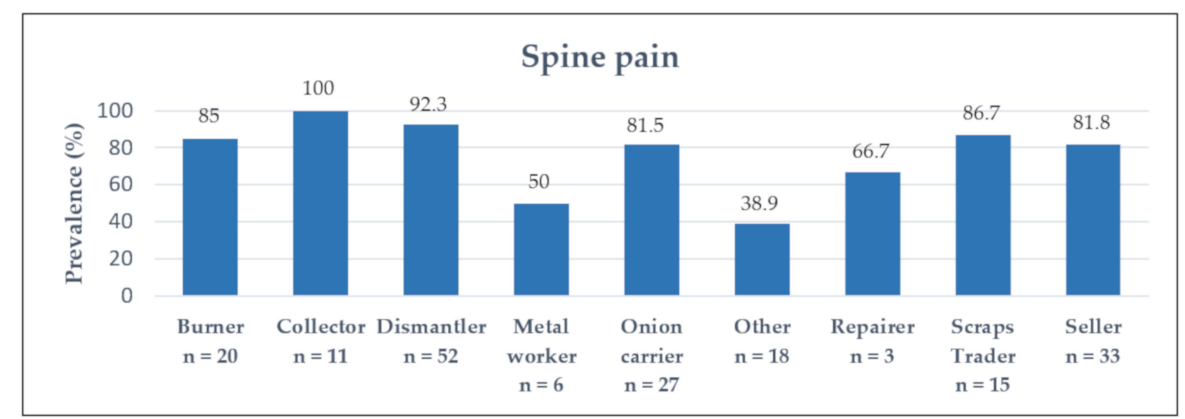

Figure 3. Frequency of back pain for all occupational groups (total number of workers $n=178$ ).

\section{Discussion}

To the best of our knowledge, this study was the first to comprehensively investigate work-related diseases in a study population of workers in Accra's informal e-waste sector. This study compared symptoms and diseases with a group of non-e-waste workers, working at the Agbogbloshie recycling site without being involved in e-waste processing.

Both the e-waste workers and the control group reported many similar health problems, such as malaria, digestive problems, or mental disorders. The report of similar health problems is not completely unexpected. Both groups had a similar age distribution. The overall number of participating women was small, although there was a significantly higher number of females in the control group. Both groups had a similar smoking behavior and a similar conduct in seeking medical care. Both groups were exposed to Anopheles spp. during their work (Agbogbloshie is directly located next to a lagoon), which explains the malaria infections. Similarities in dietary habits could explain the common digestive problems. Finally, the high prevalence of mental problems among all participants can be explained by 
the migration history of most workers from both groups. Having migrated from poverty in remote areas (from northern Ghana as well as from neighboring countries) the mainly young men enter a challenging environment full of stressors and insecurities in Agbogbloshie. Experiences of violence and discrimination might increase their vulnerability to psychiatric disorders.

However, red itchy eyes, back pain, and work-related injuries had a statistically significant higher frequency in the group of e-waste workers. Red itchy eyes among e-waste workers can most likely be related to the direct exposure to fumes and smoke for the burners and irritating chemicals by manual dismantling. Another common symptom of e-waste workers was back pain, whether caused by lifting heavy objects or sitting in a bent position, while the electronic part is locked in place with the feet and broken open with a hammer and chisel. The forced working posture of dismantlers, as well as the lifting and carrying of heavy objects by onion carriers and sellers, might be responsible for severe musculoskeletal symptoms. Therefore, back pain was also frequently reported in the control group. The high consumption of drugs (e.g., cannabis), in addition to the use of painkillers, could be a way of dealing with the chronic pain and the intolerable working conditions. The high frequency of work-related injuries can be explained by specific work tasks, such as the manual dismantling. The workers suffer cuts, mainly on the upper extremities, from the pointed tools used for stripping the equipment. Gloves are rarely worn. An important co-factor concerning injuries could be the significantly higher substance abuse among e-waste workers. As demonstrated, an association between drug use and the likelihood of injury could be observed.

These results can be integrated into the existing literature. Burns et al. and Yu et al. assessed injuries among the e-waste workers at Agbogbloshie, although Burns et al. focused on the role of noise exposure and Yu et al. predominantly explored the health knowledge of e-waste workers $[16,17,19]$. Ohajinwa et al. observed that cuts on hands/fingers among e-waste workers were the most common injuries [18]. Here, a connection with the lack of PPE and the job designation was suspected, which we also observed. Similar occupational injuries were found among workers with solid waste in Addis Ababa, Ethiopia [20]. Among workers in the recycling sector in Santo André, Brazil, Gutberlet et al. not only noticed cuts and fractures, but the workers also described body pain, which was linked to ergometric causes [21], as seen in our study.

Besides occupational related factors, environmental conditions play a major role in Agbogbloshie as well. Being one of the world's most toxic places [3], the severe pollution of water, air, and soil has to be taken into account while assessing adverse health effects. In 2013, Norman et al. reviewed studies on the role of environmental factors on health. Chemicals from the environment in air, water, and food are associated with an increased probability of a wide variety of non-communicable diseases [22]. A noxious exposure especially in early childhood development is described as being clearly associated with the pathogenesis of cancer [23], asthma [24], neurodevelopmental conditions [25], obesity [26], and chronic diseases $[27,28]$. Regarding the specific contamination by electronic waste, Grant et al. compiled all known health implications in a comprehensive review in 2013 [14]. Restricted thyroid function [29], cellular expression and function [30], adverse neonatal outcomes [31,32], changes in temperament and behavior [33,34], and decreased lung function [35] were detectable. There was a clear association with abortions [31], stillbirth, reduced birthweights [32], and DNA damage [36]. The extent of environmental contamination by informal e-waste recycling was investigated in various other studies. Caravanos et al. detected traces of aluminum, copper, iron, lead, and zinc in air samples and elevated levels of lead in soil samples at Agbogbloshie [7]. Oteng-Ababio et al. showed elevated PBDE levels in ashes, soils, and vegetables from Agbogbloshie [8]. Otsuka et al. found increased trace metal values in the earth of the Agbogbloshie market [37]. A study conducted by Greenpeace describes chemical contamination of soil on the site and in the sediment of the lagoon [9]. The results of a study by Hosoda et al. suggested a PCB (polychlorinated biphenyls) load of the Ghanaian coast by the e-waste site in Agbogbloshie [38]. In Guiyu's electric scrap heap in China, the world's largest, contamination of the earth with PAH and the riverine environment with heavy metals was attributed to e-waste related activities $[39,40]$. Sepulveda et al. summarized that very high levels of $\mathrm{Pb}, \mathrm{PBDEs}, \mathrm{PCDD} / \mathrm{Fs}$ 
(polychlorinated dibenzodioxins/difurans), and PBDD/Fs (polybrominated dibenzodioxins/difurans) in air, bottom ash, dust, soil, water, and sediments were found in e-waste sites in China and India [41].

Based on this, Robinson already concluded in 2009 that local contamination at the site of e-waste activities, where e-waste workers are exposed to toxins through skin contact and inhalation, would spread into groundwater, air, and food chains of the environment [42]. Alabi et al. carried out a comparative cross-sectional study in Lagos, Nigeria, in 2015, which dealt with the public health effects on workers and residents. On the Alaba International Market and the Computer Village Market, the two largest markets for electrical goods in Nigeria, e-waste is either burned or simply disposed of in the market area. All workers and residents reported changes in the smell and taste of drinking water and health problems (aches, migraine, nausea, spontaneous abortions, and cancer) that were significantly different from an unexposed control group [43]. It is therefore not surprising that the bystanders also show symptoms that could be caused by the toxic substances in their environment.

Our study has several limitations. First, we could not apply a validated screening tool to systematically assess work related and non-work-related symptoms and diseases. In the absence of such a tool, we used focused questions based on ICD-10 (International Statistical Classification of Diseases and Related Health Problems) specifications after extensive consultation with occupational physicians and local project support. However, clear clinical diagnoses, physical measurements, and laboratory testing rather than self-reported complaints would have allowed more valid conclusions. As described, the study population was very heterogeneous in terms of regional origin and education. The questions therefore had to be translated into different languages with the help of interpreters, which may have affected their consistency. In addition, many subjects had low health literacy. This explains why not all answers could always be evaluated. The recall bias is also inherent in the system. Not all past complaints could be reliably described by the subjects. In addition, the healthy worker effect could have caused a bias towards a healthier study population, if sick workers did not show up at work and therefore did not appear in the study.

The results of our study provide concrete indications on how to improve the situation of workers by occupational health interventions. Although our study could only be a momentary snapshot, our findings should lead to clear actions. As Yu et al. already stated, many of the e-waste workers do not have sufficient knowledge about the health risks of their work [19]. Occupational safety training and equipping workers with adequate tools and personal protection equipment is therefore urgently needed. At the same time, our results clearly show the need for local medical care. Further research should focus on the long-term damage of informal e-waste recycling but should not lose sight of the existing needs.

\section{Conclusions}

The majority of the reported health problems did not differ between the e-waste workers and the control group of workers without involvement in e-waste processing. However, red itchy eyes, back pain, and work-related injuries were more frequent in the e-waste workers group. The occurrence of red itchy eyes can be explained by the exposure to eye irritating substances, such as fumes or chemicals during burning or manual dismantling. Back pain is a typical symptom for working in forced positions or by carrying heavy loads. Manual dismantling using inadequate work tools elevates the risk for work-related injuries. All of these adverse health conditions can be reduced by occupational safety training and the use of personal protection equipment. Since workers at the Agbogbloshie recycling site who were not involved into e-waste processing also frequently reported adverse health effects, these particular groups of workers should also get into the focus of occupational health research. An urgent need for occupational health interventions, adequate medical care, and more in-depth future research is clearly evident. 
Author Contributions: Conceptualization, D.F., F.S., and A.K.; formal analysis, D.F. and A.K.; resources, D.F., J.Y., and F.S.; writing-original draft preparation, D.F.; writing—review and editing, D.F., F.S., J.Y., M.K.F., C.G., and A.K.; supervision, A.K., T.K., and J.N.F.; and project administration, C.G., J.N.F., and A.K. All authors have read and agreed to the published version of the manuscript.

Funding: This research was funded by the GIZ GmbH (German Society for International Cooperation).

Acknowledgments: First, we want to thank the chairman of the Scrap Dealers' Association, Mr. Mohamed Ali, for supporting our project at the recycling site. We gratefully thank Aminu Salawu and Ahmed A Rabyi Ahmed Gazati for recruiting participants, as well as supporting us with their language skills. We thank the staff of the GHS (Ghana Health Service) for organizing the screening day at the health post, who enabled us to recruit workers and bystanders for this study. Finally, we deeply thank all participants for answering our questions and dedicating their precious work time to make this study possible.

Conflicts of Interest: Fatima Seidu had a consultancy contract with the GIZ during the assessment. All other authors declare no conflict of interest. The funders had no role in the design of the study; in the collection, analyses, or interpretation of data; in the writing of the manuscript, or in the decision to publish the results.

\section{References}

1. Baldé, C.P.; Forti, V.; Gray, V.; Kuehr, R.; Stegmann, P. The Global E-Waste Monitor-2017; United Nations University (UNU), International Telecommunication Union (ITU) \& International Solid Waste Association (ISWA): Bonn, Germany; Geneva, Switzerland; Vienna, Austria, 2017; pp. 4-7. Available online: http://collections.unu.edu/eserv/UNU:6341/Global-E-waste_Monitor_2017_electronic_ single_pages_.pdf (accessed on 6 October 2019).

2. Schluep, M.; Manhart, A.; Osibanjo, O.; Rochat, D.; Isarin, N.; Mueller, E. Where are WEee in Africa? Findings from the Basel Convention E-Waste Africa Program; Secretariat of the Basel Convention: Châtelaine, Switzerland, 2011; pp. 19-24. Available online: http://www.basel.int/Portals/4/download.aspx?d=UNEP-CHW-EWASTEPUB-WeeAfricaReport.English.pdf (accessed on 6 October 2019).

3. Blacksmith Institute. The World's Worst 2013: The Top Ten Toxic Threats. Cleanup, Progress and Ongoing Challenges; Blacksmith Institute (now: Pure earth): New York, NY, USA, 2013; pp. 10-12. Available online: https://www.worstpolluted.org/docs/TopTenThreats2013.pdf (accessed on 6 October 2019).

4. Amankwaa, E.F.; Tsikudo, A.K.A.; Bowman, J. Recyclers at Risk; E-33113-GHA-1 Working Paper; International Growth Centre, London School of Economic and Political Science: London, UK, 2016. Available online: https://www.theigc.org/wp-content/uploads/2016/11/Armankwaa-and-Tsikudo-2016working-paper.pdf (accessed on 6 October 2019).

5. Amoyaw-Osei, Y.; Agyekum, O.O.; Pwamand, J.A.; Mueller, E.; Fasko, R.; Schluep, M. Ghana e-Waste Country Assessment; SBC e-Waste Africa Project; Secretariat of the Basel Convention: Châtelaine, Switzerland, 2011; pp. 1-3. Available online: http://www.basel.int/Portals/4/Basel\%20Convention/docs/eWaste/EwasteAssessmentGhana.pdf (accessed on 6 October 2019).

6. Akormedi, M.; Asampong, E.; Fobil, J.N. Working conditions and environmental exposures among electronic waste workers in Ghana. Int. J. Occup. Environ. Health 2013, 9, 278-286. [CrossRef]

7. Caravanos, J.; Clarke, E.E.; Osei, C.S.; Amoyaw-Osei, Y. Exploratory Health Assessment of Chemical Exposures at E-Waste Recycling and Scrapyard Facility in Ghana. J. Heal. Pollut. 2013, 3, 11-22. [CrossRef]

8. Oteng-Ababio, M.; Chama, M.A.; Amankwaa, E.F. Qualitative analysis of the presence of PBDE in ashes, soils and vegetables from Agbogbloshie e-waste recycling site. E3 J. Environ. Res. Manag. 2014, 5, 71-80, ISSN: 2141-7466.

9. Brigden, K.; Labunska, I.; Santillo, D.; Johnston, P. Chemical Contamination at e-Waste Recycling and Disposal Sites in Accra and Korforidua, Ghana; Greenpeace International: Amsterdam, The Netherlands, 2008. Available online: http://www.greenpeace.to/publications/chemical-contamination-at-e-wa.pdf (accessed on 6 October 2019).

10. Srigboh, R.K.; Basu, N.; Stephens, J.; Asampong, E.; Perkins, M.; Neitzel, R.L.; Fobil, J. Multiple elemental exposures amongst workers at the Agbogbloshie electronic waste (e-waste) site in Ghana. Chemosphere 2016, 164, 68-74. [CrossRef] [PubMed]

11. Wittsiepe, J.; Feldt, T.; Till, H.; Burchard, G.; Wilhelm, M.; Fobil, J.N. Pilot study on the internal exposure to heavy metals of informal-level electronic waste workers in Agbogbloshie, Accra, Ghana. Environ. Sci. Pollut. Res. 2017, 24, 3097-3107. [CrossRef] [PubMed] 
12. Feldt, T.; Fobil, J.N.; Wittsiepe, J.; Wilhelm, M.; Till, H.; Zoufaly, A.; Burchard, G.; Göen, T. High levels of PAH-metabolites in urine of e-waste recycling workers from Agbogbloshie, Ghana. Sci. Total Environ. 2014, 466-467, 369-376. [CrossRef] [PubMed]

13. Asante, K.A.; Agusa, T.; Biney, C.A.; Agyekum, W.A.; Bello, M.; Otsuka, M.; Itai, T.; Takahashi, S.; Tanabe, S. Multi-trace element levels and arsenic speciation in urine of e-waste recycling workers from Agbogbloshie, Accra in Ghana. Sci. Total Environ. 2012, 424, 63-73. [CrossRef] [PubMed]

14. Grant, K.; Goldizen, F.C.; Sly, P.D.; Brune, M.; Neira, M.; van den Berg, M.; Norman, R.E. Health consequences of exposure to e-waste: A systematic review. Lancet Glob. Heal. 2013, 1, e350-e361. [CrossRef]

15. Asampong, E.; Dwuma-Badu, K.; Stephens, J.; Srigboh, R.; Neitzel, R.; Basu, N.; Fobil, J.N. Health seeking behaviours among electronic waste workers in Ghana. BMC Public Health 2015, 15, 1-9. [CrossRef]

16. Burns, K.N.; Sun, K.; Fobil, J.N.; Neitzel, R.L. Heart rate, stress, and occupational noise exposure among electronic waste recycling workers. Int. J. Environ. Res. Public Health 2016, 13, 140. [CrossRef]

17. Burns, K.N.; Sayler, S.K.; Neitzel, R.L. Stress, health, noise exposures, and injuries among electronic waste recycling workers in Ghana. J. Occup. Med. Toxicol. 2019, 14, 1-11. [CrossRef] [PubMed]

18. Ohajinwa, C.M.; Van Bodegom, P.M.; Vijver, M.G.; Olumide, A.O.; Osibanjo, O.; Peijnenburg, W.J.G.M. Prevalence and injury patterns among electronic waste workers in the informal sector in Nigeria. Inj. Prev. 2018, 24, 185-192. [CrossRef]

19. Yu, E.A.; Akormedi, M.; Asampong, E.; Meyer, C.G.; Fobil, J.N. Informal processing of electronic waste at Agbogbloshie, Ghana: workers' knowledge about associated health hazards and alternative livelihoods. Glob. Health Promot. 2017, 24, 90-98. [CrossRef] [PubMed]

20. Bogale, D.; Kumie, A.; Tefera, W. Assessment of occupational injuries among Addis Ababa city municipal solid waste collectors: A cross-sectional study. BMC Public Health 2014, 14, 1-8. [CrossRef] [PubMed]

21. Gutberlet, J.; Baeder, A.M. Informal recycling and occupational health in Santo André, Brazil. Int. J. Environ. Health Res. 2008, 18, 1-15. [CrossRef]

22. Norman, R.E.; Carpenter, D.O.; Scott, J.; Brune, M.N.; Sly, P.D. Environmental exposures: An underrecognized contribution to noncommunicable diseases. Rev. Environ. Health 2013, 28, 59-65. [CrossRef]

23. Lichtenstein, P.; Holm, N.V.; Verkasalo, P.K.; Iliadou, A.; Kaprio, J.; Koskenvou, M.; Pukkala, E.; Skytthe, A.; Hemminki, K. Environmental and Heritable Factors in the Causation of Cancer-Analyses of Cohorts of Twins from Sweden, Denmark, and Finland. N. Engl. J. Med. 2000, 343, 78-85. [CrossRef]

24. Soto-Martinez, M.; Sly, P.D. Relationship between environmental exposures in children and adult lung disease: The case for outdoor exposures. Chron. Respir. Dis. 2010, 7, 173-186. [CrossRef]

25. Lanphear, B.P.; Hornung, R.; Khoury, J.; Yolton, K.; Baghurst, P.; Bellinger, D.C.; Canfield, R.L.; Dietrich, K.N.; Bornschein, R.; Greene, T.; et al. Low-level environmental lead exposure and children's intellectual function: An international pooled analysis. Eviron. Health. Perspect. 2005, 113, 894-899. [CrossRef]

26. Dirinck, E.; Jorens, P.G.; Covaci, A.; Geens, T.; Roosens, L.; Neels, H.; Mertens, I.; Van Gaal, L. Obesity and Persistent Organic Pollutants: Possible Obesogenic Effect of Organochlorine Pesticides and Polychlorinated Biphenyls. Obesity 2011, 19, 709-714. [CrossRef]

27. Lee, D.; Lee, I.; Song, K.; Steffes, M.; Toscano, W.; Baker, B.A.; Jacobs, D.R. A strong dose-response relation between serum concentrations of persistent organic pollutants and diabetes: Results from the National Health and Examination Survey 1999-2002. Diabetes Care 2006, 29, 1638-1644. [CrossRef] [PubMed]

28. Goncharov, A.; Pavuk, M.; Foushee, H.R.; Carpenter, D.O. For the Anniston Environmental Health Research Consortium. Blood Pressure in Relation to Concentrations of PCB Congeners and Chlorinated Pesticides. Eviron. Health. Perspect. 2011, 119, 319-325. [CrossRef] [PubMed]

29. Wang, H.; Zhang, Y.; Liu, Q.; Wang, F.; Nie, J.; Qian, Y. Examining the relationship between brominated flame retardants (BFR) exposure and changes of thyroid hormone levels around e-waste dismantling sites. Int. J. Environ. Health 2010, 213, 369-380. [CrossRef] [PubMed]

30. Li, Y.; Huo, X.; Liu, J.; Peng, L.; Li, W.; Xu, X. Assessment of cadmium exposure for neonates in Guiyu, an electronic waste pollution site of China. Environ. Monit. Assess. 2011, 177, 343-351. [CrossRef]

31. Wu, K.; Xu, X.; Peng, L.; Liu, J.; Guo, Y.; Huo, X. Association between maternal exposure to perfluorooctanoic acid (PFOA) from electronic waste recycling and neonatal health outcomes. Environ. Int. 2012, 48, 1-8. [CrossRef]

32. Xu, X.; Yang, H.; Chen, A.; Zhou, Y.; Wu, K.; Liu, J.; Zhang, Y.; Huo, X. Birth outcomes related to informal e-waste recycling in Guiyu, China. Reprod. Toxicol. 2012, 33, 94-98. [CrossRef] 
33. Liu, J.; Xu, X.; Wu, K.; Piao, Z.; Huang, J.; Guo, Y.; Li, W.; Zhang, Y.; Chen, A.; Huo, X. Association between lead exposure from electronic waste recycling and child temperament alterations. Neurotoxicology 2011, 32, 458-464. [CrossRef]

34. Li, Y.; Xu, X.; Wu, K.; Chen, G.; Liu, J.; Chen, S.; Gu, C.; Zhang, B.; Zheng, L.; Zheng, M.; et al. Monitoring of lead load and its effect on neonatal behavioral neurological assessment scores in Guiyu, an electronic waste recycling town in China. J. Environ. Monit. 2008, 10, 1233-1238. [CrossRef]

35. Zheng, G.; Xu, X.; Li, B.; Wu, K.; Yekeen, T.A.; Huo, X. Association between lung function in school children and exposure to three transition metals from an e-waste recycling area. J. Expo. Sci. Environ. Epidemiol. 2013, 23, 67-72. [CrossRef]

36. Liu, Q.; Cao, J.; Li, K.Q.; Miao, X.H.; Li, G.; Fan, F.Y.; Zhao, Y.C. Chromosomal aberrations and DNA damage in human populations exposed to the processing of electronics waste. Environ. Sci. Pollut. Res. 2009, 16, 329-338. [CrossRef]

37. Otsuka, M.; Itai, T.; Asante, K.A.; Muto, M.; Tanabe, S. Trace Element Contamination around the E-waste Recycling Site at Agbogbloshie, Accra City, Ghana. Interdiscip. Stud. Environ. Chem. 2012, 6, 161-167.

38. Hosoda, J.; Ofosu-Anim, J.; Sabi, E.B.; Akita, L.G.; Onwona-Agyeman, S.; Yamashita, R.; Takada, H. Monitoring of organic micropollutants in Ghana by combination of pellet watch with sediment analysis: E-waste as a source of PCBs. Mar. Pollut. Bull. 2014, 86, 575-581. [CrossRef] [PubMed]

39. Yu, X.Z.; Gao, Y.; Wu, S.C.; Zhang, H.B.; Cheung, K.C.; Wong, M.H. Distribution of polycyclic aromatic hydrocarbons in soils at Guiyu area of China, affected by recycling of electronic waste using primitive technologies. Chemosphere 2006, 65, 1500-1509. [CrossRef]

40. Wong, C.S.C.; Duzgoren-Aydin, N.S.; Aydin, A.; Wong, M.H. Evidence of excessive releases of metals from primitive e-waste processing in Guiyu, China. Environ. Pollut. 2007, 148, 62-72. [CrossRef] [PubMed]

41. Sepúlveda, A.; Schluep, M.; Renaud, F.G.; Streicher, M.; Kuehr, R.; Hagelüken, C.; Gerecke, A.C. A review of the environmental fate and effects of hazardous substances released from electrical and electronic equipments during recycling: Examples from China and India. Environ. Impact Assess. Rev. 2010, 30, 28-41. [CrossRef]

42. Robinson, B.H. E-waste: An assessment of global production and environmental impacts. Sci. Total Environ. 2009, 408, 183-191. [CrossRef]

43. Alabi, O.A.; Bakare, A.A. Perceived public health effects of occupational and residential exposure to electronic waste in Lagos, Nigeria. Zoologist 2015, 13, 62-71, ISSN 1596 972X. 